\title{
Metabolizable energy levels in diets with high lysine for growing and finishing pigs
}

\section{Níveis de energia metabolizável em rações com alta lisina para suínos em crescimento e terminação}

\author{
Soraia Viana Ferreira ${ }^{1}$; Lívia Maria dos Reis Barbosa ${ }^{2}$; Camila Schultz Marcolla \\ Marcos Henrique Soares²; Dante Teixeira Valente Júnior²; Gustavo Amorim \\ Rodrigues $^{4}$; Alysson Saraiva ${ }^{5 *}$
}

\begin{abstract}
The objective of this experiment was to evaluate the effects of metabolizable energy (ME) levels in diets with high digestible lysine concentration on performance, carcass traits, and meat quality of barrows from 95 to 158 days of age. Eighty commercial hybrid barrows $(50 \pm 1.82 \mathrm{~kg})$ selected for lean meat deposition, were assigned to four dietary treatments $(3,150,3,235,3,320$, and 3,400 kcal EM kg-1) in a randomized design with 10 replicate pens per treatment and two pigs per pen. From 95 to 116 days of age, we observed no effects of ME on final body weight (FBW), average daily gain (ADG), metabolizable energy intake (MEI), and feed conversion (F: G). Average daily feed intake (ADFI) decreased linearly with increasing ME levels $\left(\hat{\mathrm{Y}}=5.79961-0.00096790 \mathrm{X}-\mathrm{r}^{2}=0.89\right)$. From 95 to 137 days of age, no effects of ME were observed on final body weight (FBW), average daily gain (ADG), metabolizable energy intake (MEI), and feed conversion (F: G). Average daily feed intake (ADFI) decreased linearly with increasing $\mathrm{ME}\left(\hat{\mathrm{Y}}=6.1176-0.001 \mathrm{X}-\mathrm{r}^{2}=0.97\right)$. From 95 to 158 days, of age no effects of ME were observed on FBW and ADG. Dietary ME influenced the ADFI and F: G, which decreased linearly with increasing ME concentrations $\left(\hat{Y}=8.12951-0.00149 \mathrm{X}-\mathrm{r}^{2}=0.99 ; \hat{\mathrm{Y}}=6.0914-\right.$ $0.001 \mathrm{X}-\mathrm{r}^{2}=0.75$, respectively). There was a linear increase in loin eye area (LEA) with increasing ME $\left(\hat{\mathrm{Y}}=-29.851+0.0207 \mathrm{X}-\mathrm{r}^{2}=0.87\right)$. Backfat thickness, $\mathrm{pH}$, and temperature, measured at different times after slaughter ( $0 \mathrm{~min}, 45 \mathrm{~min}, 3 \mathrm{~h}$, and $24 \mathrm{~h}$ ), were not affected by dietary ME. The level of ME also did not affect the meat quality parameters Color L*, Color $\mathrm{a}^{*}$, Color $\mathrm{b}^{*}$, Warner-Bratzler shear force, thaw water losses, cooking water losses, sum of water losses, intramuscular fat content, and TBARS. Diets with 3,400 kcal kg-1 ME, corresponding to 2.75, 2.57, and $2.31 \mathrm{~g}$ digestible lysine/Mcal of ME for pigs from 95 to 116,116 to 137 , and 95 to 158 days of age, respectively, resulted in best performance and carcass traits, without negative effects on meat quality.
\end{abstract}

Key words: Carcass traits. Nutritional requirement. Pork quality.

\footnotetext{
${ }^{1}$ Discente de Doutorado em Zootecnia, Universidade Federal de Minas Gerais, UFMG, Belo Horizonte, MG, Brasil. E-mail: soraiavianazoo@yahoo.com.br

2 Discentes, Programa de Pós-Graduação em Zootecnia, Universidade Federal de Viçosa, UFV, Viçosa, MG, Brasil. E-mail: liviareisbarbosa@yahoo.com.br; marcos.henrique@ufv.br; dante.junior@ufv.br

3 Discente de Doutorado em Zootecnia, Universidade de Alberta, Alberta, Canadá. E-mail: camila marcolla@hotmail.com

4 Discente de Graduação em Zootecnia, UFV, Viçosa, MG, Brasil. E-mail: Gustavoamotim638@gmail.com

5 Prof., Departamento de Zootecnia, UFV, Viçosa, MG, Brasil. E-mail: alysson.saraiva@ufv.br

* Author for correpsondence
} 


\section{Resumo}

Objetivou-se com este experimento avaliar os efeitos de níveis de energia metabolizável (EM) em rações com alta lisina no desempenho, nas características de carcaça e na qualidade de carne de suínos machos castrados, dos 95 aos 158 dias de idade. Foram utilizados 80 suínos (Agroceres PIC), machos castrados, com peso inicial de $50 \pm 1,82 \mathrm{~kg}$. Os animais foram distribuídos em delineamento inteiramente casualizado, com quatro tratamentos $\left(3150 \mathrm{kcal} \mathrm{EM} \mathrm{kg}^{-1}, 3235 \mathrm{kcal} \mathrm{EM} \mathrm{kg}{ }^{-1}, 3320 \mathrm{kcal}\right.$ $\mathrm{EM} \mathrm{kg}{ }^{-1}, 3400 \mathrm{kcal} \mathrm{EM} \mathrm{kg}^{-1}$ ), dez repetições e dois animais por unidade experimental, representada pela baia. No período de 95 a 116 dias de idade, não foram observados efeitos dos níveis de EM sobre os parâmetros de desempenho: peso médio final (PMF), ganho de peso médio diário (GPD), consumo de energia metabolizável (CEM) e conversão alimentar (CA). O consumo de ração médio diário (CDR) reduziu de forma linear com o aumento dos níveis de EM da ração ( $\hat{Y}=5,79961-0,00096790 \mathrm{X}-\mathrm{r}^{2}=$ 0,89). No período de 95 a 137 dias de idade, não foram observados efeitos dos níveis de EM sobre os parâmetros de desempenho: peso médio final (PMF), ganho de peso médio diário (GPD), consumo de energia metabolizável (CEM) e conversão alimentar (CA). O consumo de ração médio diário (CDR) reduziu de forma linear com o aumento dos níveis de EM da ração ( $\left.\hat{Y}=6,1176-0,001 X-r^{2}=0,97\right)$. No período de 95 a 158 dias de idade, não foram observados efeitos dos níveis de EM sobre o PMF e o GPD dos suínos. O CDR e a CA dos animais reduziram de forma linear com o aumento dos níveis de EM da ração ( $\hat{Y}=8,12951-0,00149 \mathrm{X}-\mathrm{r}^{2}=0,99$ e $\hat{\mathrm{Y}}=6,0914-0,001 \mathrm{X}-\mathrm{r}^{2}=0,75$; respectivamente). Verificou-se aumento linear da área de olho de lombo com o aumento do nível de EM das rações, ( $\hat{Y}$ $\left.=-29851+0,0207 \mathrm{X}-\mathrm{r}^{2}=0.87\right)$. A espessura de toucinho, o $\mathrm{pH}$ e a temperatura medida em diferentes tempos após o abate ( 0 min, 45 min, 3 horas e 24 horas) não foram influenciados pelos níveis de EM da ração. Não foi observado efeito dos níveis de EM sobre os parâmetros de qualidade carne: Cor L*, Cor $\mathrm{a}^{*}$, Cor $\mathrm{b}^{*}$, força de cisalhamento Warner-Bratzler, perda de água no descongelamento, perda de água na cocção, perda de água total, gordura intramuscular e TBARS. Rações com 3400 kcal de EM $\mathrm{kg}^{-1}$, correspondendo às relações de 2,75; 2,57 e 2,31 g de lisina digestível/Mcal de EM, dos 95 aos 116, dos 116 aos 137 e dos 95 aos 158 dias de idade, respectivamente, resultam em melhor desempenho e características de carcaça, sem efeitos negativos na qualidade da carne de suínos machos castrados.

Palavras-chave: Características de carcaça. Exigência nutricional. Qualidade de carne.

\section{Introduction}

Maximizing growth rates, improving nutrient use efficiency, and reducing production costs are some of the main objectives of pig production systems (MAIN et al., 2008; ZHANG et al., 2011).

Lysine, the first limiting amino acid in diets based on corn and soybean meal for pigs, which is mainly used in muscle protein synthesis (MEZA et al., 2015), has a direct influence on the achievement of these objectives. In addition to lysine, energy, considered the most important component in pig production costs (LÉTOURNEAU-MONTMINY et al., 2011), also considerably influences pig performance. In the growth and finishing phases, the energy concentration of the diet can influence the feed intake of pigs fed ad libitum (ZOU et al., 2014). In this way, the intake of amino acids can be altered as the energy level of the diet changes. Therefore, it is important to consider an optimal ratio between digestible lysine and metabolizable energy when the amino acid or energy contents of the diet change (LI et al., 2012).

A number of studies have been carried out to determine the optimum ratio of lysine to energy in diets for growing and finishing pigs (MAIN et al., 2008; ZOU et al., 2014). However, the optimal level of metabolizable energy in diets with high lysine has not been specified, although such information could contribute to improve performance, carcass traits, and pork quality, since these variables are associated with dietary energy levels.

In this context, this study was conducted to evaluate the effects of metabolizable energy levels on high-lysine diets on performance, carcass traits, 
and pork quality of castrated male pigs from 95 to 158 days of age.

\section{Material and Methods}

Eighty pigs (Agroceres PIC), castrated males, 95 days of age and with an initial weight of $50 \pm$ $1.82 \mathrm{~kg}$, were used. The pigs were assigned in a completely randomized design with four dietary metabolizable energy (EM) levels $(3,150,3,235$, 3,320 , and 3,400 kcal $\mathrm{kg}^{-1}$ ), with 10 replicates and two pigs per pen.

The pigs were housed in pens with semiautomatic feeders, nipple drinkers, and concrete floors. The environmental conditions inside the facility were monitored daily at 16:00 through maximum and minimum thermometers kept in an empty pen at approximately half the height of the pigs' bodies.

The compositions of the experimental diets used from 95 to 116,116 to 137 , and 137 to 158 days of age are shown in Tables 1, 2, and 3, respectively. The diets were mainly composed of corn and soybean meal and supplemented with minerals and vitamins to meet the nutritional requirements of the pigs at each phase, according to Rostagno et al. (2011), with the exception of metabolizable energy (ME) and digestible lysine (LD). The LD: ME ratio of the diets with 3,400 kcal of $\mathrm{kg}^{-1} \mathrm{ME}$ in each phase was maintained as recommended in Rostagno et al. (2011).

Table 1. Composition of experimental diets fed to pigs from 95 to 116 days of age.

\begin{tabular}{|c|c|c|c|c|}
\hline \multirow{2}{*}{ Ingredient, $\mathrm{g} \mathrm{kg}^{-1}$} & \multicolumn{4}{|c|}{ Metabolizable energy, kcal kg-1 } \\
\hline & 3150 & 3235 & 3320 & 3400 \\
\hline Corn & 700.32 & 700.32 & 700.32 & 700.32 \\
\hline Soybean meal & 220.0 & 220.0 & 220.0 & 220.0 \\
\hline Soybean oil & 11.00 & 21.00 & 31.50 & 41.50 \\
\hline Dicalcium phosphate & 10.50 & 10.50 & 10.50 & 10.50 \\
\hline Limestone & 6.00 & 6.00 & 6.00 & 6.00 \\
\hline Salt & 4.00 & 4.00 & 4.00 & 4.00 \\
\hline Clay filler & 40.22 & 30.22 & 19.72 & 9.72 \\
\hline Mineral premix $^{1}$ & 8.80 & 8.80 & 8.80 & 8.80 \\
\hline Vitamin premix ${ }^{2}$ & 8.80 & 8.80 & 8.80 & 8.80 \\
\hline L-lysine $\mathrm{HCl}$ & 34.0 & 34.0 & 34.0 & 34.0 \\
\hline DL-methionine & 10.0 & 10.0 & 10.0 & 10.0 \\
\hline L-threonine & 10.0 & 10.0 & 10.0 & 10.0 \\
\hline L-tryptophan & 10.0 & 10.0 & 10.0 & 10.0 \\
\hline Antioxidant ${ }^{3}$ & 10.0 & 10.0 & 10.0 & 10.0 \\
\hline Choline chloride, $60 \mathrm{~g} \mathrm{~kg}^{-1}$ & 60.0 & 60.0 & 60.0 & 60.0 \\
\hline \multicolumn{5}{|l|}{ Calculated nutritional composition ${ }^{4}$} \\
\hline ME, kcal kg-1 & 3150 & 3235 & 3320 & 3400 \\
\hline Crude protein, $\mathrm{g} \mathrm{kg}^{-1}$ & 160.5 & 160.5 & 160.5 & 160.5 \\
\hline Digestible Lysine, $\mathrm{g} \mathrm{kg}^{-1}$ & 9.39 & 9.39 & 9.39 & 9.39 \\
\hline Digestible Lysine:ME, g Mcal-1 & 2.98 & 2.90 & 2.83 & 2.75 \\
\hline
\end{tabular}


continuation

\begin{tabular}{lllll} 
Digestible Met+Cys, $\mathrm{g} \mathrm{kg}^{-1}$ & 5.54 & 5.54 & 5.54 & 5.54 \\
Digestible Threonine, $\mathrm{g} \mathrm{kg}^{-1}$ & 6.10 & 6.10 & 6.10 & 6.10 \\
Digestible Tryptophan, $\mathrm{g} \mathrm{kg}^{-1}$ & 1.69 & 1.69 & 1.69 & 1.69 \\
Sodium, $\mathrm{g} \mathrm{kg}^{-1}$ & 1.70 & 1.70 & 1.70 & 1.70 \\
Calcium, $\mathrm{g} \mathrm{kg}^{-1}$ & 5.82 & 5.82 & 5.82 & 5.82 \\
Available phosphorus, $\mathrm{g} \mathrm{kg}^{-1}$ & 2.82 & 2.82 & 2.82 & 2.82 \\
Choline, $\mathrm{mg} \mathrm{kg}^{-1}$ & 3.28 & 3.28 & 3.28 & 3.28 \\
\hline
\end{tabular}

${ }^{1}$ Provided per kg of diet: Fe (100 mg), Cu (10 mg), Co (1 mg); Mn (40 mg), Zn (100 mg), I (1,5 mg), and Se (0,22 mg). ${ }^{2}$ Provided per kg of diet: vit. A (8.000 UI), vit. D3 (1.200 UI), vit. E (20 UI), vit. K3 (2 mg), vit. B1 (1 mg), vit. B2 (4 mg), nicotinic acid (22 $\mathrm{mg})$, pantothenic acid $(16 \mathrm{mg})$, vit. B6 (0,50 mg), vit. B12 (0,020 mg), folic acid (0,4 mg), biotin (0,120 mg), choline (400 mg), antioxidant $(30 \mathrm{mg}) .{ }^{3}$ Butil-hidroxi-tolueno (BHT).

${ }^{4}$ Values calculated according to Rostagno et al. (2011).

The pigs had free access to feed and water. Throughout the experimental period, diets were weighed before feeding, and leftovers and feed wastes were manually collected and weighed daily to determine average daily feed intake (ADFI) and metabolizable energy intake (MEI). The pigs were weighed individually, without fasting at 95, 116, and 137 days of age, and fasted at 158 days of age (end of experiment) to determine final body weight (FBW), average daily weight gain (ADG), and feed conversion (F: G).

Table 2. Composition of experimental diets fed to pigs from 116 to 137 days of age.

\begin{tabular}{|c|c|c|c|c|}
\hline \multirow{2}{*}{ Ingredient, $\mathrm{g} \mathrm{kg}^{-1}$} & \multicolumn{4}{|c|}{ Metabolizable energy, $\mathrm{kcal} \mathrm{kg}^{-1}$} \\
\hline & 3150 & 3235 & 3320 & 3400 \\
\hline Corn & 733.80 & 733.80 & 733.80 & 733.80 \\
\hline Soybean meal & 190.00 & 190.00 & 190.00 & 190.00 \\
\hline Soybean oil & 9.00 & 19.00 & 29.50 & 39.50 \\
\hline Dicalcium phosphate & 9.50 & 9.50 & 9.50 & 9.50 \\
\hline Limestone & 6.00 & 6.00 & 6.00 & 6.00 \\
\hline Salt & 3.50 & 3.50 & 3.50 & 3.50 \\
\hline Clay filler & 40.45 & 30.45 & 19.95 & 9.95 \\
\hline Mineral premix ${ }^{1}$ & 0.75 & 0.75 & 0.75 & 0.75 \\
\hline Vitamin premix ${ }^{2}$ & 0.75 & 0.75 & 0.75 & 0.75 \\
\hline L-lysine $\mathrm{HCl}$ & 3.40 & 3.40 & 3.40 & 3.40 \\
\hline DL-methionine & 0.95 & 0.95 & 0.95 & 0.95 \\
\hline L-threonine & 1.10 & 1.10 & 1.10 & 1.10 \\
\hline L-tryptophan & 0.15 & 0.15 & 0.15 & 0.15 \\
\hline Antioxidant ${ }^{3}$ & 0.10 & 0.10 & 0.10 & 0.10 \\
\hline Choline chloride, $60 \mathrm{~g} \mathrm{~kg}^{-1}$ & 0.55 & 0.55 & 0.55 & 0.55 \\
\hline \multicolumn{5}{|c|}{ Calculated nutritional composition ${ }^{4}$} \\
\hline ME, kcal kg-1 & 3150 & 3235 & 3320 & 3400 \\
\hline Crude protein, $\mathrm{g} \mathrm{kg}^{-1}$ & 150.1 & 150.1 & 150.1 & 150.1 \\
\hline
\end{tabular}


continuation

$\begin{array}{lllll}\text { Digestible Lysine, } \mathrm{g} \mathrm{kg}^{-1} & 8.74 & 8.74 & 8.74 & 8.74 \\ \text { Digestible Lysine:ME, } \mathrm{g} \mathrm{Mcal}^{-1} & 2.77 & 2.70 & 2.63 & 2.57 \\ \text { Digestible Met+Cys, } \mathrm{g} \mathrm{kg}^{-1} & 5.24 & 5.24 & 5.24 & 5.24 \\ \text { Digestible Threonine, } \mathrm{g} \mathrm{kg}^{-1} & 5.85 & 5.85 & 5.85 & 5.85 \\ \text { Digestible Tryptophan, } \mathrm{g} \mathrm{kg}^{-1} & 1.57 & 1.57 & 1.57 & 1.57 \\ \text { Sodium, g kg-1 } & 1.60 & 1.60 & 1.60 & 1.60 \\ \text { Calcium, g kg-1 } & 5.40 & 5.40 & 5.40 & 5.40 \\ \text { Available phosphorus, } \mathrm{g} \mathrm{kg}^{-1} & 2.63 & 2.63 & 2.63 & 2.63 \\ \text { Choline, } \mathrm{mg} \mathrm{kg}^{-1} & 2.80 & 2.80 & 2.80 & 2.80\end{array}$

${ }^{1}$ Provided per kg of diet: Fe (100 mg), Cu (10 mg), Co (1 mg); Mn (40 mg), Zn (100 mg), I (1,5 mg), and Se (0,22 mg). ${ }^{2}$ Provided per kg of diet: vit. A (8.000 UI), vit. D3 (1.200 UI), vit. E (20 UI), vit. K3 (2 mg), vit. B1 (1 mg), vit. B2 (4 mg), nicotinic acid (22 $\mathrm{mg})$, pantothenic acid $(16 \mathrm{mg})$, vit. B6 $(0,50 \mathrm{mg})$, vit. B12 $(0,020 \mathrm{mg})$, folic acid $(0,4 \mathrm{mg})$, biotin $(0,120 \mathrm{mg})$, choline (400 mg), antioxidant (30 mg). ${ }^{3}$ Butil-hidroxi-tolueno (BHT).

${ }^{4}$ Values calculated according to Rostagno et al. (2011).

At the end of the experimental period (158 days of age), all pigs, after weighing, underwent a 12hour fasting period with free access to water, and only one pig from each experimental unit with body weight closest to $115 \mathrm{~kg}$ was sent to slaughter. The pigs were electrically stunned and exsanguinated, according to the guidelines of animal welfare.

The carcasses were divided longitudinally and all measurements and samples were taken using the right half carcass. The $\mathrm{pH}$ and temperature of the carcasses were measured immediately after slaughtering and at 45 minutes after slaughtering. Subsequently, the carcasses were stored and chilled to $5^{\circ} \mathrm{C}$ in a cold chamber, where the $\mathrm{pH}$ was measured at 3 and 24 hours after slaughtering. The $\mathrm{pH}$ was measured on the Longissimus dorsi muscle, at the height of the last rib, using a portable $\mathrm{pH}$ meter (Testo SE \& Co., Lenzkirch, FR, Germany) with an insertion electrode and an attached thermometer.

Table 3. Composition of experimental diets fed to pigs from 137 to 158 days of age.

\begin{tabular}{lcccc}
\hline \multirow{2}{*}{ Ingredientes, $\mathrm{g} \mathrm{kg}^{-1}$} & \multicolumn{4}{c}{ Metabolizable energy, $\mathrm{kcal} \mathrm{kg}^{-1}$} \\
\cline { 2 - 4 } & 3150 & 3235 & 3320 & 3400 \\
\hline Corn & 778.00 & 778.00 & 778.00 & 778.00 \\
Soybean meal & 150.00 & 150.00 & 150.00 & 150.00 \\
Soybean oil & 6.50 & 17.00 & 27.00 & 37.50 \\
Dicalcium phosphate & 9.00 & 0.900 & 0.900 & 0.900 \\
Limestone & 5.00 & 0.500 & 0.500 & 0.500 \\
Salt & 3.50 & 0.350 & 0.350 & 0.350 \\
Clay filler & 40.51 & 30.61 & 20.61 & 10.11 \\
Mineral premix & 1 & 0.62 & 0.62 & 0.62 \\
Vitamin premix & 0.62 & 0.62 & 0.62 & 0.62 \\
L-lysine $\mathrm{HCl}$ & 0.62 & 3.45 & 3.45 & 3.45
\end{tabular}




\begin{tabular}{|c|c|c|c|c|}
\hline DL-methionine & 0.75 & 0.75 & 0.75 & 0.75 \\
\hline L-threonine & 0.95 & 0.95 & 0.95 & 0.95 \\
\hline L-tryptophan & 0.15 & 0.15 & 0.15 & 0.15 \\
\hline Antioxidant ${ }^{3}$ & 0.10 & 0.10 & 0.10 & 0.10 \\
\hline Choline chloride, $60 \mathrm{~g} \mathrm{~kg}^{-1}$ & 0.45 & 0.45 & 0.45 & 0.45 \\
\hline \multicolumn{5}{|l|}{ Calculated nutritional composition ${ }^{4}$} \\
\hline ME, $\mathrm{kcal} \mathrm{kg}^{-1}$ & 3150 & 3235 & 3320 & 3400 \\
\hline Crude protein, $\mathrm{g} \mathrm{kg}^{-1}$ & 136.2 & 136.2 & 136.2 & 136.2 \\
\hline Digestible Lysine, $\mathrm{g} \mathrm{kg}^{-1}$ & 7.88 & 7.88 & 7.88 & 7.88 \\
\hline Digestible Lysine:ME, $\mathrm{g} \mathrm{Mcal}^{-1}$ & 2.50 & 2.43 & 2.37 & 2.31 \\
\hline Digestible Met + Cys, $\mathrm{g} \mathrm{kg}^{-1}$ & 4.73 & 4.73 & 4.73 & 4.73 \\
\hline Digestible Threonine, $\mathrm{g} \mathrm{kg}^{-1}$ & 5.28 & 5.28 & 5.28 & 5.28 \\
\hline Digestible Tryptophan, $\mathrm{g} \mathrm{kg}^{-1}$ & 1.42 & 1.42 & 1.42 & 1.42 \\
\hline Sodium, $\mathrm{g} \mathrm{kg}^{-1}$ & 1.50 & 1.50 & 1.50 & 1.50 \\
\hline Calcium, $\mathrm{g} \mathrm{kg}^{-1}$ & 5.00 & 5.00 & 5.00 & 5.00 \\
\hline Available phosphorus, $\mathrm{g} \mathrm{kg}^{-1}$ & 2.43 & 2.43 & 2.43 & 2.43 \\
\hline Choline, $\mathrm{mg} \mathrm{kg}^{-1}$ & 2.30 & 2.30 & 2.30 & 2.30 \\
\hline
\end{tabular}

${ }^{1}$ Provided per kg of diet: Fe (100 mg), Cu (10 mg), Co (1 mg); Mn (40 mg), Zn (100 mg), I (1,5 mg), and Se (0,22 mg). ${ }^{2}$ Provided per kg of diet: vit. A (8.000 UI), vit. D3 (1.200 UI), vit. E (20 UI), vit. K3 (2 mg), vit. B1 (1 mg), vit. B2 (4 mg), nicotinic acid (22 $\mathrm{mg})$, pantothenic acid $(16 \mathrm{mg})$, vit. B6 (0,50 mg), vit. B12 (0,020 mg), folic acid (0,4 mg), biotin (0,120 mg), choline (400 mg), antioxidant $(30 \mathrm{mg}) .{ }^{3}$ Butil-hidroxi-tolueno (BHT).

${ }^{4}$ Values calculated according to Rostagno et al. (2011).

After 24 hours of chilling, backfat thickness at P2 (BFP2) was measured using a digital caliper, and to determine the Longissimus dorsi area, the muscular surface between the 10th and the 11th rib was covered with a polyethylene sheet and contoured using a permanent marker with a thin point. The sheets were digitally scanned and colored. Colored areas within the contour were measured using an image analysis software (ImageJ 128 version $1.49 \mathrm{t}$, National Institutes of Health, Bethesda, MD).

A 30-cm sample of the Longissimus dorsi from each right carcass was collected, separating the muscles between the last thoracic vertebra and the first lumbar vertebra. The samples were then vacuum-packed in polyethylene plastic bags, frozen at $-20^{\circ} \mathrm{C}$ for 24 hours, and then cut crosswise using a tabletop saw, thus obtaining 2.54-cm thick chops that were packaged, identified, and re-frozen at $-20^{\circ} \mathrm{C}$ for further analysis (BRIDI; SILVA, 2007).
For color analysis, Longissimus dorsi chops were thawed and exposed to air for 30 minutes for the reaction of myoglobin with atmospheric oxygen subsequently, the color was evaluated using a portable spectrophotometer (Hunter MiniScan EZ, 4500L; Hunter Associates Laboratory, Inc., Reston, VA) appropriately calibrated prior to data collection. The mean values of $\mathrm{L}^{*}$ (lightness), $\mathrm{a}^{*}$ (redness), and $b^{*}$ (yellowness) of each sample were determined by averaging three readings on three different points of the chop surface.

For water loss determination, frozen chops were removed from packs, weighed, and allowed to thaw at $4{ }^{\circ} \mathrm{C}$ for 12 hours. After thawing, the chops were gently wiped using paper towel, weighed, placed on a perforated grill, and broiled in an electric oven (Layr, Luxo Inox, Jundiaí, SP, Brazil) preheated to $170^{\circ} \mathrm{C}$. Temperature was monitored using a thermocouple inserted into the geometric center 
of the chops (Omega engineering, Stamford, CT), attached to a digital monitor. The chops were turned over when the internal temperature reached $35^{\circ} \mathrm{C}$, and removed from the oven when at an initial temperature of $71^{\circ} \mathrm{C}$. The samples were chilled at $4^{\circ} \mathrm{C}$ for 12 hours and then re-weighed. Thaw and cook water losses were expressed as a percentage of the chop weight before each procedure (BRIDI; SILVA, 2007).

After weighing, cooked chops were used to determine the Warner-Bratzler shear force (WBSF) as proposed by the American Meat Science Association (2016), with minor modifications. From each sample, six round cores, measuring $1.27 \mathrm{~cm}$ in diameter, were removed parallel to the longitudinal orientation of the muscle fibers, using a sharp stainless-steel coring device. These round cores were sheared once through the center, perpendicularly to the longitudinal orientation of the muscle fibers, using a V-notch blade with a thickness of $1.016 \mathrm{~mm}$ and an angle of $60^{\circ}$ at a fixed speed of $20 \mathrm{~cm} \mathrm{~min}^{-1}$, coupled to a Warner-Bratzler Shear machine (G-R Electrical Manufacturing Company, Manhattan, KS). The WBSF was is presented as the mean of six measures and expressed in $\mathrm{kgf}$.

Intramuscular fat quantification was performed via the ether extraction method (EE, method 2007.04; AOAC, 2007), using an automated extractor XT20 Fat Analyzer, (Ankom Technology Corporation, Fairport, NY, USA). The samples were conditioned on Ankom filters and subsequently sealed. The filters containing the samples were dried in an oven at $100^{\circ} \mathrm{C}$ for 3 hours and subsequently transferred to a desiccator for cooling, weighed, and transferred to the filter holder of the extraction unit. Extraction in the fat analyzer was performed using petroleum ether for a period of 30 minutes in a closed chamber at $90^{\circ} \mathrm{C}$. After extraction, the residue-containing filters were transferred to an oven at $100^{\circ} \mathrm{C}$ to dry for $60 \mathrm{~min}$. The filters were then packed into a desiccator and weighed. The EE content was determined by the reduction of sample mass after extraction.
Determination of lipid oxidation was carried out using the technique of thiobarbituric acid reactive substances (TBARS), proposed by Rosmini et al. (1996).

The data were analyzed using the software package PROC REG (SAS INSTITUTE, 1985), following a completely randomized design and considering the initial body weight as covariate. Estimation of the best level of metabolizable energy was performed by means of regression analysis, according to the best fit of the data. Probability values less than $5 \%$ were considered significant.

\section{Results and Discussion}

Throughout the experiment, the average temperature inside the facility was $20.4 \pm 1.75^{\circ} \mathrm{C}$. The maximum and minimum temperatures recorded daily were $25.4 \pm 1.82^{\circ} \mathrm{C}$ and $15.3 \pm$ $1.72^{\circ} \mathrm{C}$, respectively, with a mean humidity of $79.4 \%$. According to Sampaio et al. (2004), the thermoneutrality range for pigs in the growth and finishing phases ranges between 15 and $22^{\circ} \mathrm{C}$, which leads us to infer that the pigs in our study were submitted to periods of heat stress.

The ADFI of the pigs from 95 to 116 days of age decreased linearly $(\mathrm{P}=0.01)$ with increasing metabolizable energy (ME) density in the diet (Table 4) $\left(\hat{\mathrm{Y}}=5.79961-0.00096790 \mathrm{X}-\mathrm{r}^{2}=0.89\right)$. These results corroborate those of Beaulieu et al. (2009) when studying levels of digestible energy (DE) varying from 3,090 to $3,570 \mathrm{kcal} \mathrm{kg}^{-1}$ and ratios of $3.09,2.24,3.34,3.42$, and $3.57 \mathrm{~g}$ digestible lysine/Mcal of DE for pigs in the growth phase (30 to $60 \mathrm{~kg}$ ); these authors also observed a reduction in ADFI as DE increased. On the other hand, De La Llata et al. (2001) observed no variations in ADFI of growing pigs due to the increase in the energy density of the diet when the DL: ME ratio was kept constant. These results suggest that the influence of ME density on the feed intake of growing pigs can vary, irrespective whether the ratio between lysine and feed energy is maintained. 
Table 4. Performance and carcass traits of pigs fed different levels of metabolizable energy in diets with high lysine from 95 to 158 days of age.

\begin{tabular}{|c|c|c|c|c|c|c|c|}
\hline \multirow{2}{*}{ Item } & \multicolumn{4}{|c|}{ Metabolizable energy, $\mathrm{kcal} \mathrm{kg}^{-1}$} & \multirow{2}{*}{$\mathrm{CV}, \%$} & \multicolumn{2}{|c|}{$P$ value } \\
\hline & 3150 & 3235 & 3320 & 3400 & & Linear & Quadratic \\
\hline \multicolumn{8}{|c|}{95 to 116 days of age } \\
\hline IBW, $\mathrm{kg}$ & 51.41 & 51.45 & 51.58 & 51.15 & - & - & - \\
\hline FBW, kg & 74.45 & 72.46 & 73.72 & 72.78 & 1.65 & 0.24 & 0.47 \\
\hline $\mathrm{ADG}, \mathrm{kg}$ & 1.099 & 1.002 & 1.062 & 1.043 & 5.02 & 0.39 & 0.18 \\
\hline ADFI, $\mathrm{kg}^{1}$ & 2.757 & 2.633 & 2.635 & 2.482 & 1.73 & 0.01 & 0.84 \\
\hline MEI, kcal day ${ }^{-1}$ & 8688 & 8510 & 8747 & 8458 & 2.45 & 0.65 & 0.80 \\
\hline $\mathrm{F}: \mathrm{G}$ & 2.51 & 2.63 & 2.48 & 2.38 & 3.72 & 0.13 & 0.17 \\
\hline \multicolumn{8}{|c|}{95 to 137 days of age } \\
\hline FBW, kg & 100.16 & 97.45 & 98.56 & 99.06 & 0.99 & 0.64 & 0.14 \\
\hline $\mathrm{ADG}, \mathrm{kg}$ & 1.161 & 1.0996 & 1.123 & 1.134 & 2.09 & 0.64 & 0.14 \\
\hline ADFI, $\mathrm{kg}^{2}$ & 3.092 & 3.034 & 2.959 & 2.846 & 0.15 & 0.04 & 0.59 \\
\hline MEI, kcal day ${ }^{-1}$ & 9740 & 9815 & 9824 & 9687 & 0.18 & 0.83 & 0.53 \\
\hline $\mathrm{F}: \mathrm{G}^{1}$ & 2.66 & 2.78 & 2.63 & 2.51 & 2.38 & 0.01 & 0.10 \\
\hline \multicolumn{8}{|c|}{95 to 158 days of age } \\
\hline FBW, kg & 125.36 & 121.38 & 122.04 & 122.80 & 0.82 & 0.27 & 0.11 \\
\hline $\mathrm{ADG}, \mathrm{kg}$ & 1.174 & 1.110 & 1.121 & 1.133 & 1.43 & 0.27 & 0.11 \\
\hline ADFI, $\mathrm{kg}^{3}$ & 3.454 & 3.318 & 3.206 & 3.070 & 0.23 & $<0.001$ & 0.99 \\
\hline MEI, kcal day ${ }^{-1}$ & 10880 & 10735 & 10645 & 10455 & 0.32 & 0.11 & 0.90 \\
\hline$F: G^{4}$ & 2.94 & 2.99 & 2.85 & 2.71 & 1.35 & $<0.001$ & 0.40 \\
\hline LEA, $\mathrm{cm}^{5}$ & 36.06 & 36.80 & 37.95 & 41.55 & 2.18 & 0.02 & 0.30 \\
\hline $\mathrm{BF}, \mathrm{mm}$ & 18.51 & 18.64 & 17.37 & 16.36 & 2.10 & 0.19 & 0.66 \\
\hline
\end{tabular}

IBW = initial body weight $(\mathrm{kg}), \mathrm{ADG}=$ average daily gain $(\mathrm{g}), \mathrm{ADFI}=$ average daily feed intake $(\mathrm{kg}), \mathrm{MEI}=$ metabolizable energy intake, $\mathrm{F}: \mathrm{G}=$ feed conversion, $\mathrm{LEA}=$ Loin eye area; $\mathrm{BF}=$ backfat at $\mathrm{P} 2$.

${ }^{1} \hat{Y}=5.79961-0.00096790 X\left(r^{2}=0.89\right)$

${ }^{2} \hat{Y}=6.1176-0.001 X\left(r^{2}=0.97\right)$

${ }^{3} \hat{Y}=8.12951-0.00149 X\left(r^{2}=0.99\right)$

${ }^{4} \hat{Y}=6.0914-0.001 X\left(r^{2}=0.75\right)$

${ }^{5} \hat{Y}=-29.851+0.0207 X\left(r^{2}=0.87\right)$.

From 95 to 137 days of age, there was an effect $(\mathrm{P}=0.04)$ of the ME levels on the ADFI of the pigs (Table 4), which decreased in a linear way with the increase in ME density of the diets $(\hat{Y}=6.1176$ $\left.0.001 X-r^{2}=0.97\right)$. Similarly, Paiano et al. (2008) also verified that the increase in the net energy density of the diet resulted in a decrease in the voluntary feed intake of castrated male and female pigs from 60 to $90 \mathrm{~kg}$.

The pigs' F: G ratio from 95 to 137 days of age varied $(\mathrm{P}=0.01)$ due to the increase in the $\mathrm{ME}$ of the diets (Table 4) improving linearly $(\hat{Y}=4.9585$ $\left.0.0007 \mathrm{X}-\mathrm{r}^{2}=0.48\right)$. These results are in agreement with those obtained by Trindade Neto et al. (2005) when assessing ME and digestible lysine levels for pigs in the growth phase; the authors also observed an improvement in $F$ : $G$ due to the increase in dietary energy levels from 3,270 to $3,500 \mathrm{kcal} \mathrm{kg}^{-1}$.

From 95 to 158 days of age (Table 4), there was no effect $(\mathrm{P}>0.05)$ of ME density on FBW and ADG. Previous studies have shown significant improvements in pig ADG with increasing dietary 
energy levels only in the growth phase (DE LA LLATA et al., 2001; KERR et al., 2003). Beaulieu et al. (2009) verified that the ADG of pigs increased with increasing ME density of the diet in the growth phase, with no effect in the finishing phase. Thus, it is possible to infer that finishing pigs do not respond with an improvement in ADG when the ME of the feed increases. The absence of an effect on the FBW of pigs can be explained by the fact that the ME density of the diets did not significantly influence the ADG of the pigs.

The pigs' ADFI decreased $(\mathrm{P}<0.001)$ linearly $\left(\hat{Y}=8.12951-0.00149 \mathrm{X}-\mathrm{r}^{2}=0.99\right)$ with the increase in ME density. A negative correlation between dietary ME density and the ADFI of pigs has also been observed by Ettle et al. (2003). In this sense, in studies conducted by Rezende et al. (2006) to evaluate levels of ME in diets for finishing pigs, with a constant digestible lysine ratio, a negative correlation between these two factors was also evidenced. These results confirm the findings of Gonçalves et al. (2015), who observed that diets with high energy density negatively influence the voluntary feed intake of pigs. Rezende et al. (2006) suggested that this is a mechanism to adjust feed intake to meet the energy requirement, since pigs can compensate for low dietary energy densities by increasing daily feed intake until the energy requirement is met.

There was no effect $(\mathrm{P}>0.05)$ of the ME density of the diets on the MEI of pigs from 95 to 158 days of age. As the ADFI of the pigs decreased linearly with the increase in the ME concentration in the diet, the absence of such an effect corroborates the mechanism of pigs to increase consumption when fed with diets with low energy in order to meet their ME requirements.

Increasing the ME density of the diets for pigs from 95 to 158 days of age also influenced $(\mathrm{P}<$ 0.001 ) the F: $G$ of the animals (Table 4), which increased linearly $\left(\hat{\mathrm{Y}}=6.0914-0.001 \mathrm{X}-\mathrm{r}^{2}=0.75\right)$. Similar results have been observed by Rezende et al.
(2006) and, more recently, by Jin et al. (2010), using diets in which the ME ratios with digestible lysine were kept constant. The consistent results obtained in the present study, regarding the effects of dietary ME density on the ADFI and F: G of the pigs in the different periods evaluated may be related to the possible positive effects on the metabolism of the long-chain fatty acids contained in soybean oil.

According to Mateos and Sell (1980), lipids reduce the transit velocity of digesta through the gastrointestinal tract. Therefore, increasing the inclusion levels of soybean oil in pig diets may result in better energy digestibility, which would be consistent with the findings of a lower ADFI and an improvement in the F: G ratio of the pigs in this study. The increase in feed transit velocity of digesta with the use of dietary soybean oil would be related to the effects of long-chain fatty acids on the stimulation and production of cholecystokinin by the intestinal mucosa (FORSSTEN et al., 2013) and to the production of neurotensin by ileum $\mathrm{N}$ cells (INAGAKI et al., 2012), both hormones with recognized action to reduce gastric emptying of pigs, among other effects.

The increase in ME density of the diets resulted in a linear $\left(\hat{\mathrm{Y}}=-29.851+0.0207 \mathrm{X}-\mathrm{r}^{2}=0.87\right)$ increase in loin eye area (LEA) $(\mathrm{P}=0.02)$ (Table 4). Positive effects of dietary ME density on LEA of pigs have also been reported by Hinson et al. (2011). As LEA is positively correlated with the percentage of meat in the carcass (CISNEROS et al., 1996), it is possible to infer that the increase in ME levels of the diets positively influenced protein deposition in the carcass. This proposition is consistent with the $\mathrm{F}$ : $\mathrm{G}$ ratios obtained in the present study.

On the other hand, Chu et al. (2012), evaluating DE levels varying from 3,250 to $3,491 \mathrm{kcal} \mathrm{kg}^{-1}$, observed a linear decrease in LEA with increasing energy densities. In addition to possible differences in the genetic potential for lean meat deposition, the inconsistency of results between the studies may also be related to the LD: ED ratios (1.87, 
$1.81,1.74,1.68,1.66)$ in the study of Chu et al. (2012), which decreased as DE levels increased and may have limited protein synthesis, resulting in lower LEA values. In the present study, however, the LD: ME ratio was maintained according to the recommendations of Rostagno et al. (2011).

There was no effect $(\mathrm{P}>0.05)$ of the $\mathrm{ME}$ density of the diets on BF of pigs (Table 4). In the literature, effects on $\mathrm{BF}$ of pigs due to the increase in the concentration of ME of the diet vary widely. Similar to the present study, Rezende et al. (2006), evaluating ME levels ranging from 3,100 to 3,500 $\mathrm{kcal} \mathrm{kg}{ }^{-1}$ for castrated male pigs, also found no differences in BF. Beaulieu et al. (2009), however, evaluating the effects of ED levels varying from 3,090 to $3,570 \mathrm{kcal} \mathrm{kg}^{-1}$ on performance parameters and pig carcass traits in the growth phase (30 to 60 $\mathrm{kg}$ ), observed an increase in BF with increasing DE level of the diets. However, the lack of any effect of dietary ME density on the BF of the pigs in the present study can be explained by the absence of a difference in MEI among the diets.

The $\mathrm{pH}$ is one of the most important determinants of pork quality because it directly influences color and water retention capacity, which in turn will influence juiciness, softness, taste, shelf life, and consumer acceptance (KIM et al., 2016). In the present study, the $\mathrm{pH}$ and temperature values of the carcass were not influenced by the ME levels of the diets (Table 5). These results are in agreement with those found by Jin et al. (2010), who, evaluating $\operatorname{ME}\left(3,265 ; 3,365\right.$; and $\left.3,465 \mathrm{kcal} \mathrm{kg}^{-1}\right)$ for finishing pigs, also found no differences in the $\mathrm{pH}$ of pork at 45 minutes and 24 hours after slaughter. According to Sarcinelli et al. (2007), if the pH is below 5.8 in less than 4 hours after slaughter, the meat can be classified as PSE (pale, soft, and exudative) meat, while at a $\mathrm{pH}$ above 6.2 at 24 hours after slaughter, the meat retains large amounts of water and can be classified as DFD meat (dark, hard, and dry, with a shorter shelf-life). Based on our results, PSE or DFD meats did not predominate in our study.

Meat color values (Table 5), measured via the values of $\mathrm{L}^{*}, \mathrm{a}^{*}$, and $\mathrm{b}^{*}$, were not influenced $(\mathrm{P}>$ $0.05)$ by the diets. These results are in agreement with those found by Suarez-Belloch et al. (2013), who evaluated net energy (NE) levels for finishing pigs and also found no effects of diet on pork color. Similarly, Zeng et al. (2012) observed no differences in pork color of pigs fed different levels of DE. Meng et al. (2010), however, observed a reduction in $\mathrm{L}^{*}$ and $\mathrm{b}^{*}$ values in the Longissimus dorsi when the metabolizable energy levels of the diets increased from 3,400 to $3500 \mathrm{kcal} \mathrm{kg}^{-1}$. A possible explanation for the lack of any effects on pork color values was proposed by Henckel et al. (2002), who suggested that the occurrence of significant effects on meat quality variables can only be expected if the glycogen concentrations during slaughter are below $53 \mu \mathrm{mol} \mathrm{g}{ }^{-1}$ of tissue. In the present study, there was no effect on Longissimus dorsi $\mathrm{pH}$, which leads us to infer that the concentrations of muscle glycogen were adequate at the time of slaughter. 
Table 5. Values of $\mathrm{pH}$, temperature and pork quality parameters determined in Longissimus dorsi of pigs fed different levels of metabolizable energy in diets with high lysine from 95 to 158 days of age.

\begin{tabular}{|c|c|c|c|c|c|c|c|}
\hline \multirow{2}{*}{ Item } & \multicolumn{4}{|c|}{ Metabolizable energy, $\mathrm{kcal} \mathrm{kg}^{-1}$} & \multirow{2}{*}{$\mathrm{CV}, \%$} & \multicolumn{2}{|c|}{ P value } \\
\hline & 3150 & 3235 & 3320 & 3400 & & Linear & Quadratic \\
\hline \multicolumn{8}{|l|}{$\mathrm{pH}$} \\
\hline $0 \mathrm{~min}$ & 6.47 & 6.45 & 6.47 & 6.55 & 0.02 & 0.45 & 0.50 \\
\hline $45 \mathrm{~min}$ & 6.35 & 6.36 & 6.31 & 6.52 & 1.11 & 0.13 & 0.15 \\
\hline 3 hours & 5.96 & 6.21 & 5.88 & 6.12 & 4.20 & 0.69 & 0.94 \\
\hline 24 hours & 5.50 & 5.54 & 5.46 & 5.58 & 1.37 & 0.42 & 0.39 \\
\hline \multicolumn{8}{|c|}{ Temperature } \\
\hline $0 \mathrm{~min}$ & 32.65 & 33.11 & 32.66 & 32.70 & 0.95 & 0.92 & 0.97 \\
\hline $45 \mathrm{~min}$ & 25.51 & 25.24 & 25.83 & 26.95 & 0.26 & 0.28 & 0.50 \\
\hline 3 hours & 19.35 & 19.43 & 20.57 & 17.73 & 5.81 & 0.49 & 0.23 \\
\hline 24 hours & 8.86 & 8.27 & 8.46 & 8.26 & 3.06 & 0.53 & 0.73 \\
\hline \multicolumn{8}{|c|}{ Quality parameters } \\
\hline $\mathrm{L}^{*}$ & 54.51 & 53.11 & 54.10 & 54.37 & 1.28 & 0.87 & 0.32 \\
\hline$a^{*}$ & 7.85 & 9.23 & 8.17 & 7.80 & 8.46 & 0.55 & 0.06 \\
\hline$b^{*}$ & 15.12 & 15.18 & 14.74 & 14.72 & 1.37 & 0.26 & 0.88 \\
\hline SF, kgf & 3.82 & 3.83 & 3.38 & 3.59 & 6.75 & 0.45 & 0.77 \\
\hline TWL, \% & 5.81 & 4.58 & 4.58 & 4.57 & 5.70 & 0.23 & 0.38 \\
\hline CL, $\%$ & 27.41 & 28.08 & 25.76 & 28.58 & 6.60 & 0.80 & 0.33 \\
\hline $\mathrm{TL}, \%$ & 31.64 & 31.35 & 29.16 & 31.84 & 4.88 & 0.77 & 0.22 \\
\hline IMF, \% & 9.08 & 7.66 & 7.64 & 8.47 & 1.53 & 0.72 & 0.35 \\
\hline TBARS & 0.891 & 0.717 & 0.740 & 0.712 & 7.28 & 0.18 & 0.40 \\
\hline
\end{tabular}

$\mathrm{SF}=$ shear force, $\mathrm{TWL}=$ thawing water loss, $\mathrm{CL}=$ cooking water loss, $\mathrm{TL}=$ total water loss, $\mathrm{GIM}=$ intramuscular fat, $\mathrm{TBARS}=$ lipid oxidation with shelf life of 7 days.

Shear force (SF) was not influenced $(\mathrm{P}>0.05)$ by the diets (Table 5). This result is consistent since the $\mathrm{pH}$ and temperature of the carcasses did not change. The SF values found in this work allow classifying the pork meat as soft, since according to Iversen et al. (1995), the SF of $6.0 \mathrm{kgf}$ is established as the threshold value between soft and hard pork, and the means observed in the present study were below this value. These results, however, do not corroborate those of Matthews et al. (2003), who observed a decrease in SF by increasing ME density in the diet, accompanied by an increase in subcutaneous and intramuscular fat. These factors may have influenced meat tenderness, since fat directly affects this parameter and, as observed in the present study, the percentage of intramuscular fat (IMF) was not influenced by the diets.

Liu et al. (2007) reported that the energy density of the diet is directly related to the increase in intramuscular lipids through the modulation of the mRNA of the two enzymes fatty acid synthase and hormone-sensitive lipase, involved in the synthesis and degradation of triglycerides. However, the IMF in the present study was not influenced $(\mathrm{P}>$ 0.05 ) by increasing ME concentrations in the diets (Table 5), which is consistent with the results for SF. Similarly, Suarez-Belloch et al. (2013) also observed no differences in the percentage of IMF in the Longissimus thoracis of pigs fed different levels of NE. The different results of these studies 
in terms of the effects of dietary energy density on IMF could be due, at least in part, to the duration of the experimental period, the energy levels studied, and the genetics of the animals.

The percentages of carcass water losses during thawing (TWL) and cooking (CL) and the total loss (TL) were not influenced $(\mathrm{P}>0.05)$ by the ME levels (Table 5). Reducing the water retention capacity of the meat results in high losses in cooking, directly affecting juiciness and tenderness. The results for TL and CL were consistent throughout our study, since $\mathrm{pH}$, temperature, and SF did not vary, indicating that the ME density of the diet had no negative effect on pork quality. Similarly, Matthews et al. (2003) studied different levels of ME (3,182 to $3,413 \mathrm{kcal} \mathrm{kg}^{-1}$ ), with or without chromium addition, and also found no differences in carcass water losses. In addition, Jin et al. (2010) observed no differences in TL and CL with increasing dietary DE levels $\left(3,265 ; 3,365\right.$; and $\left.3465 \mathrm{kcal} \mathrm{kg}^{-1}\right)$.

The levels of ME did not influence $(\mathrm{P}>0.05)$ lipid oxidation (TBARS) in Longissimus dorsi samples after a shelf life of 7 days (Table 5), suggesting that the pork meat showed oxidative stability. These results are in agreement with those obtained by Meng et al. (2010), who also did not observe an effects of ME levels on the lipid oxidation of meat from castrated male pigs fed diets with 3,400 and 3,500 kcal ME $\mathrm{kg}^{-1}$, with or without probiotics. Dunshea et al. (2005) correlated TBARS values with the results of sensory analysis for odor evaluation in pork. The odor detection threshold corresponded to values between 0.5 and $1.0 \mathrm{mg}$ MDA kg-1 for trained tasters and to 0.6 and $2.0 \mathrm{mg}$ MDA $\mathrm{kg}^{-1}$ for untrained tasters. Considering the mean value of lipid oxidation found in this study ( $0.77 \mathrm{mg} \mathrm{MDA} \mathrm{kg}^{-1}$ for a shelf life of 7 days), the pork can be classified as normal.

\section{Conclusions}

The use of diets with $3,400 \mathrm{kcal} \mathrm{kg}^{-1}$ of metabolizable energy, corresponding to ratios of digestible lysine of $2.75,2.57$, and 2.31 from 95 to 116,116 to 137 , and 95 to 158 days of age, respectively, resulted in better feed conversion, lower feed intake, and improved carcass traits, without any influences on the quality of meat from castrated male pigs.

\section{Acknowledgments}

The authors would like to thank the Fundação de Amparo à Pesquisa do Estado de Minas Gerais (FAPEMIG), the Coordenação de Aperfeiçoamento de Pessoal de Nível Superior (CAPES), and the Instituto Nacional de Ciência e Tecnologia de Ciência Animal (INCT-CA) for financial support.

\section{Bioethics and Biosecurity Committee Approval}

All procedures involving animal handling were done in accordance with regulations approved by the Institutional Ethic Committee of Animals Production Use (CEUAP-UFV) of the Universidade Federal de Viçosa, Brazil. Protocol 21/2015.

\section{References}

AMERICAN MEAT SCIENCE ASSOCIATION. Research guidelines for cookery, sensory evaluation, and instrumental tenderness measurements of meat. Champaign: American Meat Science Association, 2016. $106 \mathrm{p}$.

AOAC. Official Methods of Analysis of AOAC International. $18^{\text {th }}$ ed. Washington: Association of Official Analytical Chemists, 2007. 244 p.

BEAULIEU, A. D.; WILLIAMS, N. H.; PATIENCE, J. F. Responses to dietary digestible energy concentration in growing pigs fed cereal grain-based diets. Journal of Animal Science, Champaign, v. 87, n. 3, p. 965-976, 2009.

BRIDI, A. M.; SILVA, C. A. Métodos de avaliação da carcaça e da carne suína. Londrina: Midiograf, 2007. v. $1,97 \mathrm{p}$. 
CHU, L. C.; ZHANG, G. J.; CAI, C. J.; MAO, X. B.; QIAO, S. Y. Effect of dietary energy density on performance and lean deposition of growing-finishing pigs. Journal of Animal and Veterinary Advances, Dubai, v. 11, n. 5, p. 665-675, 2012.

CISNEROS, F.; ELLIS, M.; MILLER, K. D.; NOVAKOFSKI, J.; WILSON, E. R.; MCKEITH, F. $\mathrm{K}$. Comparison of transverse and longitutinal real-time ultrasound scans for prediction of lean cut yields and fatfree lean content in live pigs. Journal of Animal Science, Champaign, v. 74, n. 11, p. 2566-2576, 1996.

DE LA LLATA, M.; DITZ, S. S.; TOKACH, M. D.; GOODBAND, R. D.; NELSSEN, J. L.; LOUGHIN, T. M. Effects of dietary fat on growth performance and carcass characteristics of growing-finishing pigs reared in a commercial environment. Journal of Animal Science, Champaign, v. 79, n. 10, p. 2643-2650, 2001.

DUNSHEA, F. R.; D’SOUZA, D. N.; PETHICK, D. W.; HARPER, G. S.; WARNER, R. D. Effects of dietary factors and other metabolic modifiers on quality and nutritional value of meat. Meat Science, Illinois, v. 71, n. 1, p. 8-38, 2005.

ETTLE, T.; ROTH-MAIER, D. A.; ROTH, F. X. Effect of apparent ileal digestible lysine to energy ratio on performance of finishing pigs at different dietary metabolizable energy levels. Journal of Animal Physiology and Animal Nutrition, Berlin, v. 87, n. 7-8, p. 269-279, 2003.

FORSSTEN, S. D.; KORCZYŃSKA, M. Z.; ZWIJSEN, R. M. L.; NOORDMAN, W. H.; MADETOJA, M.; OUWEHAND, A. C. Changes in satiety hormone concentrations and feed intake in rats in response to lactic acid bacteria. Appetite, Finland, v. 71, n. 12, p. 1621, 2013.

GONÇALVES, L. M. P.; KIEFER, C.; SOUZA, K. M. R.; MARÇAL, D. A.; ABREU, R. C.; SILVA, A. M. P. S.; ALENCAR, S. A. S. Níveis de energia líquida para suínos machos castrados em terminação. Revista Ciência Rural, Santa Maria, v. 45, n. 3, p. 464-469, 2015.

HENCKEL, P.; KARLSSON, A.; JENSEN, M. T.; OKSBJERG, N.; PETERSEN, J. S. Metabolic conditions in porcine longissimus muscle immediately pre-slaughter and its influence on peri- and post mortem energy metabolism. Meat Science, Illinois, v. 62, n. 2, p. 145$155,2002$.

HINSON, R. B.; WIEGAND, B. R.; RITTER, M. J.; ALLEE, G. L.; CARR, S. N. Impact of dietary energy level and ractopamina on growth performance, carcass characteristics, and meat quality of finishing pigs. Journal of Animal Science, Champaign, v. 89, n. 11, p. 3725-3579, 2011.
IVERSEN， P.; HENCKEL， P.; LARSEN， L. M.; MONLLAO, S.; MØLLER, A. J. Tenderisation of pork as affected by degree of cold-induced shortening. Meat Science, Illinois, v. 40, n. 2, p. 171-181, 1995.

JIN, Y. H.; OH, H. K.; PIAO, L. G.; JANG, S. K.; CHOI, Y. H.; HEO, P. S.; JANG, Y. D.; KIM, Y. Y. Effect of dietary lysine restriction and energy density on performance, nutrient digestibility and meat quality in finishing pigs. Asian-Australia Journal Animal Science, Seoul, v. 23, n. 9, p. 1213-1220, 2010.

KERR, B. J.; SOUTHERN, J. J.; BIDNER, T. D.; FRIESEN, K. G.; EASTER, R. A. Influence of dietary protein level, amino acid supplementation, and dietary energy levels on growing-finishing pig performance and carcass composition. Journal of Animal Science, Champaign, v. 81, n. 12, p. 3075-3087, 2003.

KIM, T. W.; KIM, C. W.; YANG, M. R.; NO, G. R.; KIM, S. W.; KIM, S. Pork quality traits according to port-mortem $\mathrm{pH}$ and temperature in Berkshire. Korean Journal of food Science of Animal Resources, GangnamGu, v. 36, n. 1, p. 29-36, 2016.

LÉTOURNEAU-MONTMINY, M. P.; NARCY, A.; LESCOAT, P.; MAGNIN, M.; BERNIER, J. F.; SAUVANT, D.; JONDREVILLE, C.; POMAR, C. Modeling the fate of dietary phosphorus in the digestive tract of growing pigs. Journal of Animal Science, Champaign, v. 89, n. 11, p. 3596-3611, 2011.

LI, P.; ZENG, Z.; WANG, D.; XUE, L.; ZHANG, R.; PIAO, X. Effects of the standardized ileal digestible lysine to metabolizable energy ratio on performance and carcass characteristics of growing-finishing pigs. Journal of Animal Science and Biotechnology, London, v. 3, n. 1, p. 1-9, 2012.

LIU, Z. H.; YANG, F. Y.; KING, L. J.; LAI, C. H.; PIAO, X. S.; GU, Y. H.; OU, X. Q. Effects of dietary energy density on growth, carcass quality and mRNA expression of fatty acid synthase and hormone-sensitive lipase in finishing pigs. Asian-Australasian Journal of Animal Science, Gwanak-gu, v. 20, n. 10, p. 1578-1593, 2017.

MAIN, R. G.; DRITZ, S. S.; TOKACH, M. D.; NELSSEN, J. L. Determining an optimum lysine:calorie ratio for barrows and gilts in a commercial finishing facility. Journal of animal Science, Champaign, v. 86, n. 9, p. 2190-2207, 2008.

MATEOS, G. G.; SELL, J. L. Influence of carbohydrate and supplemental fat source on the metabolizable energy of the diet. Poultry Science, v. 59, p. 2129-2135, 1980.

MATTHEWS, J. O.; HIGBIE, A. D.; SOUTHERN, L. L.; COOMBS, D. F.; BIDNER, T. D.; ODGAARD, R. L. Effect of chromium propionate and metabolizable energy 
on growth, carcass traits, and pork quality of growingfinishing pigs. Journal of Animal Science, Champaign, v. 81, n. 1, p. 191-196, 2003.

MENG, Q. W.; YAN, L.; AO, X.; ZHOU, T. X.; WANG, J. P.; LEE, J. H.; KIM, I. H. Influence of probiotics in different energy and nutrient density diets on performance, nutrient digestibility, meat quality, and blood characteristics in growth growing-finishing pigs. Journal of Animal Science, Champaign, v. 88, n. 10, p. 3320-3326, 2010.

MEZA, S. K. L.; NUNES, R. V.; TSUTSUMI, C. Y.; VIEITES, F. M.; SCHERER, C.; HENZ, J. R.; SILVA, I. M.; BAYERLE, D. F. Níveis de energia metabolizável e lisina digestível sobre a composição e rendimento de carcaça de frangos de corte. Semina: Ciências Agrárias, Londrina, v. 36, n. 2, p. 1079-1090, 2015.

NAGAKI, S.; GHIRLANDO, R.; WHITE, J. F.; GVOZDENOVIC-JEREMIC, J.; NORTHUP, J. K.; GRISSHAMMER, R. Modulation of the interaction between neurotensin receptor NTS1 and Gq protein by lipid. Journal of Molecular Biology. London, v. 417, n. 2, p. 95-111, 2012.

PAIANO, D.; MOREIRA, I.; FURLAN, A. C.; CARVALHO, P. L. O.; KURODA JUNIOR, I. S.; MARTINS, E. N. Relações treonina:lisina digestíveis e níveis de energia líquida para suínos em crescimento e terminação. Revista Brasileira de Zootecnia, Viçosa, MG, v. 37, n. 12, p. 2147-2156, 2008.

REZENDE, W. O.; DONZELE, J. L.; OLIVEIRA, R. F. M.; ABREU, M. L.; FERREIRA, A. S.; SILVA, F. C. O.; APOLÔNIO, L. R. Níveis de energia metabolizável mantendo a relação lisina digestível:caloria em rações para suínos machos castrados em terminação. Revista Brasileira de Zootecnia, Viçosa, MG, v. 35, n. 3, p. 11011106, 2006.

ROSMINI, M. R.; PERLO, F.; PÉREZ-ALVAREZ, J. A.; PAGÁN-MORENO, M. J.; GAGO-GAGO, A.; LÓPEZSANTOVEÑA, F.; ARANDA-CATALÁ, V. TBA test by na extractive method applied to pate. Meat Science, Illinois, v. 42, n. 1, p. 103-110, 1996.

ROSTAGNO, H. S.; ALBINO, L. F. T.; DONZELE, J. L.; GOMES, P. C.; OLIVEIRA, R. F.; LOPES, D. C.; FERREIRA, A. S.; BARRETO, S. L. T.; EUCLIDES, R. F. Tabelas brasileiras para aves e suínos: composição de alimentos e exigências nutricionais. 3. ed. Viçosa, MG: UFV, Departamento de Zootecnia, 2011. 252 p.

SAMPAIO, C. A. P.; CRISTANI, J.; DUBIELA, J. A.; BOFF, C. E.; OLIVEIRA, M. A. Avaliação do ambiente térmico em instalação para crescimento e terminação de suínos utilizando os índices de conforto térmico nas condições tropicais. Ciência Rural, Santa Maria, v. 34, n. 3, p. 785-790, 2004.

SARCINELLI, M. F.; SILVA, L. C.; VENTURINI, K. S. Características da carne suína. Vitória Universidade Federal do Espírito Santo, UFES, 2007. 7 p.

STATISTICAL ANALYSIS SYSTEM INSTITUTE SAS Institute. SAS user's guide: statistics. $5^{\text {th }}$ ed. Cary: SAS Institute, 1985.

SUAREZ-BELLOCH, J.; SANZ, M. A.; JOY, M.; LATORRE, M. A. Impact of increasing dietary energy level during the finishing period on growth performance, pork quality and fatty acid profile in heavy pigs. Meat Science, Illinois, v. 93, n. 4, p. 796-801, 2013.

TRINDADE NETO, M. A.; MOREIRA, J. A.; BERTO, D. A. Energia metabolizável e lisina digestível para suínos na fase de crescimento, criados em condições de segregação sanitária. Revista Brasileira de Zootecnia, Viçosa, MG, v. 34, n. 6, p. 1980-1989, 2005.

ZENG, Z.; YU, B.; MAO, X.; CHEN, D. W. Effects of dietary digestible energy concentration on growth, meat quality, and PPARY gene expression in muscle and adipose tissues of Rongchang piglets. Meat Science, Illinois, v. 90, n. 1, p. 66-70, 2012.

ZHANG, G.; YI, X.; CHU, L.; LU, N.; HTOO, J.; QIAO, S. Effects of dietary net energy density and standardized ileal digestible lysine: net energy ratio on the performance and carcass characteristic of growing-finishing pigs fed low crude protein supplemented with crystalline amino acids diets. Agricultural Sciences in China, Beijing, v. 4, n. 4, p. 602-610, 2011.

ZOU, T.; MAO, X.; YU, B.; HE, J.; ZHENG, P.; YU, J.; CHEN, D. Effects of dietary energy density and apparent ileal digestible lysine:digestible energy ratio on growth performance, meat quality, and peroxisome proliferatoractivated receptor $\gamma$ (PPAR $\gamma$ ) gene expression of muscle and adipose tissues in Landrace Rongchang crossbred pigs. Livestock Science, Amsterdam, v. 167, n.1, p. 219226, 2014. 